\title{
Impact of atmospheric species reactivity on radioactive gaseous iodine transport in severe accident conditions
}

\author{
J. Trincal ${ }^{1,3}$, L. Cantrel ${ }^{1,3}$, F. Cousin ${ }^{1,3}$, V. Fevre-Nollet ${ }^{2,3}$ \\ \& P. Lebegue ${ }^{2,3}$ \\ ${ }^{1}$ Institut de Radioprotection et de Surete Nucleaire (IRSN), PSN-RES, \\ Cadarache, Saint-Paul Lez Durance, France \\ ${ }^{2}$ Physico Chimie des Processus de Combustion et de l'Atmosphere \\ (PC2A) UMR 8522 CNRS/Lille 1, France \\ ${ }^{3}$ Laboratoire de Recherche Commun IRSN-CNRS-Lille1 "Cinetique \\ Chimique, Combustion, Reactivite" (C3R), Cadarache, \\ Saint-Paul Lez Durance, France
}

\begin{abstract}
Significant differences between measurements and modeling of iodine radiation levels resulting from the Fukushima nuclear accident could be at least partially explained by the fact that the IRSN dispersion tool does not consider chemical transformation during transport in the atmosphere.

To improve this, in a first time, a chemical mechanism of 246 gas phase reactions, including 13 photolysis reactions, coming from a detailed literature review, has been implemented in OD simulation software. Results analysis revealed that several parameters are able to influence the iodine speciation, such as the pollutant levels $\left(\mathrm{O}_{3}, \mathrm{NO}_{\mathrm{x}}, \mathrm{VOC}\right)$, the photolysis (location, season, day/night cycle) and the iodine release rate from the accident. Generally, the iodocarbon forms are predominant, obtained by reactions of iodine with atmospheric volatile organic compounds (VOC). Without organic compounds, the iodine oxides $\mathrm{I}_{\mathrm{x}} \mathrm{O}_{\mathrm{y}}$ and $\mathrm{INO}_{\mathrm{x}}$ become the main species.

Secondly, the mechanism has been implemented in a 3D chemistry-transport code, and simulations were performed in atmospheric conditions. Initial results confirm trends observed in OD calculations, i.e. the predominance of iodocarbons production.
\end{abstract}


However there are still a lot of uncertainties concerning the reactional mechanism, especially the organic part which may be incomplete and remains to be improved.

\section{Introduction}

Following a severe accident on a nuclear reactor, radionuclides produced by the fuel fission may be released to the environment, and then are carried in the atmosphere or deposited. Among the fission products, iodine is the most dangerous at short term because of its existence in gaseous and aerosol forms, and its ability to fix on the thyroid, increasing the effects of radiation on the human body.

After the Fukushima accident, the IRSN dispersion tools have been used to predict the radiological consequences. The simulations have been compared to the field measurements, highlighting significant underestimating of iodine radiation levels on the ground. Concerning the caesium, an other fission product of interest, it is mainly released in aerosol form and has a low reactivity. Its deposit levels obtained by simulation were in good agreement with the measurements.

For iodine gap, one possible explanation may be the absence of chemical iodine reactivity in the transport simulation software. In order to evaluate the impact of this reactivity on the iodine deposition, a chemical mechanism of iodine in the atmosphere has been constituted, with 246 gas phase reactions including 13 photolysis reactions, in the $\{\mathrm{I}-\mathrm{H}-\mathrm{O}-\mathrm{N}-\mathrm{C}\}$ elementary system (described in the section 2). This mechanism has been coupled to the RACM mechanism [1], which define the atmospheric pollutant reactivity.

In a first step, the iodine mechanism has then been implemented in a 0D boxmodel simulation code, and studied under representative atmospheric conditions. Parametric studies have then been lead to evaluate their influence on the iodine behaviour (described in section 3).

In a second step, the mechanism has been implemented in the $3 \mathrm{D}$ chemicaltransport code (POLAIR [2], Polyphemus platform [3]), in order to study the iodine reactivity under realistic conditions, adding the dispersion, pollutant emissions, meteorological data, initial and boundary conditions. The results of the 3D simulations will be presented in section 4 .

\section{Reactional mechanism of iodine in the atmosphere}

The strategy used to constitute the reactional mechanism of iodine was to collect all the gas phase reactions involving iodine through the literature. The kinetic databases of NIST and IUPAC has been used, as well as the IRSN knowledge on the nuclear context.

After performing the literature review, a kinetic scheme of 246 reactions has been built, including 13 photolysis reactions. The chemical system complements those used in the literature (Vogt et al. [4], McFiggans et al. [5], Calvert and 
Lindberg [6], Mahajan et al. [7], Saiz-Lopez et al. [8], Ordonez et al. [9], Sommariva et al. [10]), it is schematized in Figures 1 and 2.

These figures show that the mechanism remains to complete because of the 25 reactions without identified products and the 11 non-destroyed species. More, they are only 13 photolysis reactions for 81 iodine species. So there are many lacks of knowledge around the iodine mechanism, which could be reduced by experiment or ab-initio calculations. In the next paragraphs, this mechanism will be used in the $0 \mathrm{D}$ and $3 \mathrm{D}$ simulations, to investigate iodine behaviour in the atmosphere.

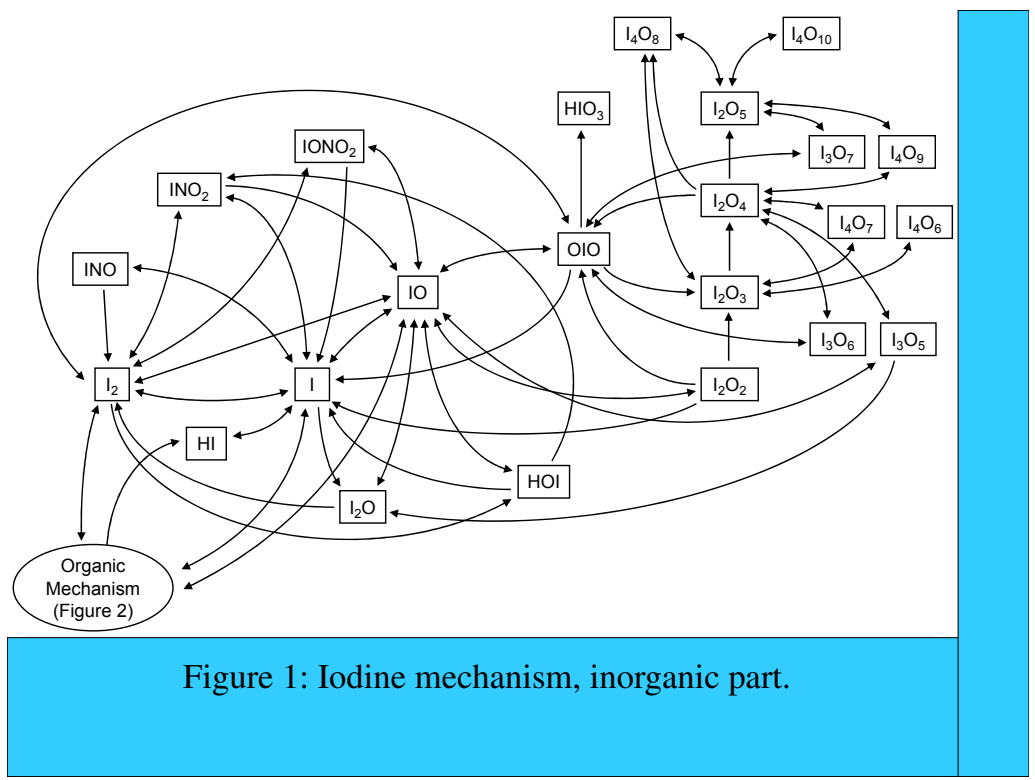

\section{OD simulations}

The iodine reactional mechanism has been implemented in a chemical solver, to perform OD simulations in a box-model with representative atmospheric boundary conditions. A continuous injection of iodine is set all along the simulation.

\subsection{Inorganic base case}

In a first step, only the inorganic mechanism has been used ( $\{\mathrm{I}-\mathrm{H}-\mathrm{O}-\mathrm{N}\}$ elementary system) to study the impact of the initial pollutant levels $\left(\mathrm{O}_{3}, \mathrm{NO}_{\mathrm{x}}\right)$, the photolysis conditions and the iodine injection rate on iodine chemical speciation.

The Inorganic Base Case is a reference simulation for atmospheric iodine behaviour, the parameters are described in Table 1. In this case, iodine is injected as $\mathrm{I}_{2}$, which is a gaseous species which may be released outside during a nuclear 


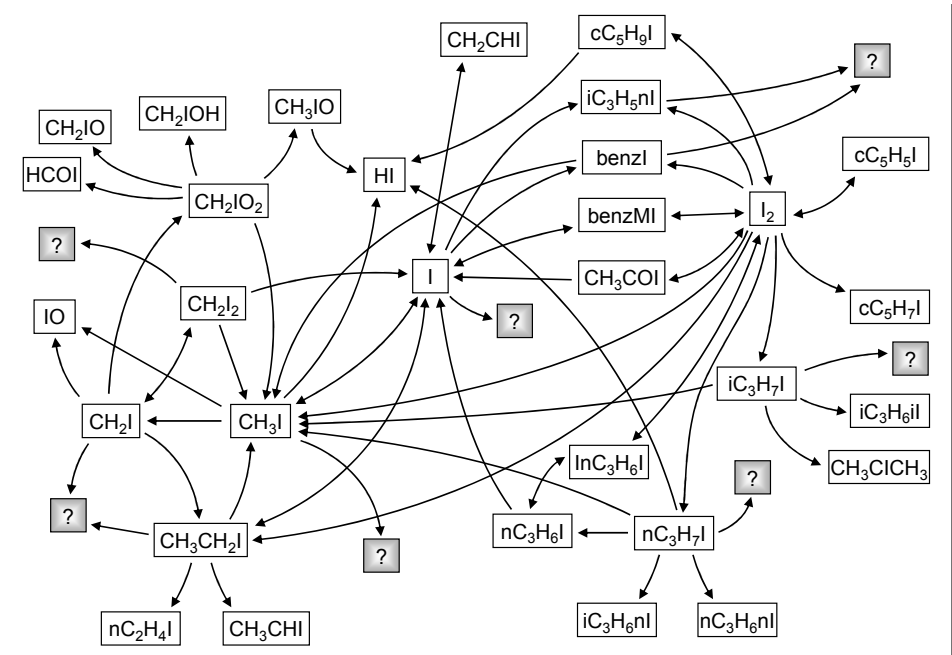

Figure 2: Iodine mechanism, organic part.

accident. The injection rate of $0.01 \mathrm{ppt.s}^{-1}$ is arbitrary, but the total injected iodine over the 10 days $(\simeq 1 \mathrm{~g})$ is in the order of magnitude of an expected potential release in case of severe accident. The molecular iodine reacts with pollutant, which are not injected during the simulation. To preserve the atmospheric pollution conditions, all the non-iodine species quantities are fixed. For this base case, the $\mathrm{O}_{3}$ and $\mathrm{NO}_{2}$ quantities are set to $25 \mathrm{ppb}$, which roughly corresponds to measured background levels.

The results (reported in Table 2) show that iodine, injected as $\mathrm{I}_{2}$, rapidly reacts with the atmospheric species $\mathrm{NO}_{\mathrm{x}}$ and $\mathrm{O}_{3}$ to form $\mathrm{IONO}_{2}$ during the night and $\mathrm{HI}$ during the day. Moreover, $\mathrm{I}_{2} \mathrm{O}_{5}$ accumulates all along the simulation, mainly produced during the day period. A second observation concerns the importance of the day/night cycle, linked to the photolysis reactions kinetic.

The analysis of the reactional paths show that this behaviour can be explained by the formation of the I and IO radicals by photolysis, these radicals being very reactive.

\subsection{Inorganic parameters sensitivity studies}

From the base case, several parameters have been studied, to define their impact on the iodine speciation. First, the pollutant ratio $\left[\mathrm{O}_{3}\right] /\left[\mathrm{NO}_{2}\right]$ have been modified from 1.0 to $1 / 500$ and 500, in order to represent typical conditions (rural or urban with wind). Secondly, the photolysis reactions have been moderated (rates calculated for January or completely removed). Finally, the injection rates of $\mathrm{I}_{2}$ 
Table 1: Box-model parameters, inorganic base case.

\begin{tabular}{|c|c|c|c|c|}
\hline $\begin{array}{l}\text { Photolysis location } \\
\text { Beginning } \\
\text { Duration }\end{array}$ & \multicolumn{4}{|c|}{$\begin{array}{l}\text { Gravelines }\left(2.11^{\circ} \mathrm{E}, 51.0^{\circ} \mathrm{N}\right) \\
2013-08-08,00: 00 \\
10 \text { days }\end{array}$} \\
\hline $\begin{array}{l}\text { Pressure } \\
\text { Temperature } \\
\text { Volume }\end{array}$ & \multicolumn{4}{|c|}{$\begin{array}{l}10^{5} \mathrm{~Pa} \\
298 \mathrm{~K} \\
10^{4} \mathrm{~m}^{3} \\
\end{array}$} \\
\hline Initial quantities & $\begin{array}{l}\mathrm{O}_{3} \\
\mathrm{H} \\
\mathrm{HO} \\
\mathrm{HNO}_{2} \\
\mathrm{H}_{2} \mathrm{O}\end{array}$ & $\begin{array}{l}25 \mathrm{ppb} \\
2.5 \times 10^{-10} \mathrm{ppb} \\
2.5 \times 10^{-04} \mathrm{ppb} \\
0.25 \mathrm{ppb} \\
73.4 \% \mathrm{RH}\end{array}$ & $\begin{array}{l}\mathrm{NO}_{2} \\
\mathrm{H}_{2} \\
\mathrm{H}_{2} \mathrm{O}_{2} \\
\mathrm{HNO}_{3} \\
\mathrm{HO}_{2}\end{array}$ & $\begin{array}{l}25 \mathrm{ppb} \\
5.5 \times 10^{+02} \mathrm{ppp} \\
1.0 \mathrm{ppb} \\
0.25 \mathrm{ppb} \\
2.5 \times 10^{-02} \mathrm{ppb}\end{array}$ \\
\hline Injection - Emission & $\mathrm{I}_{2}$ & \multicolumn{3}{|l|}{$0.01{\mathrm{ppt} . \mathrm{s}^{-1}}^{-1}$} \\
\hline Non-iodine species & \multicolumn{4}{|c|}{ Fixed quantity } \\
\hline
\end{tabular}

has been either multiplied or divided by 100 . The results of the different cases are gathered in Table 2.

It has been observed that the iodine speciation can widely vary, depending on the atmospheric conditions (pollution, photolysis, injection). The most important impact concerns the repartition between the iodine oxides $\left(\mathrm{I}_{\mathrm{x}} \mathrm{O}_{\mathrm{y}}\right)$, the iodine nitroxides $\left(\mathrm{INO}_{\mathrm{x}}\right)$ and the molecular forms $\left(\mathrm{HI}, \mathrm{HOI}, \mathrm{I}_{2}\right)$. Indeed, when there are no photolysis reactions, the iodine predominant form is $\mathrm{IONO}_{2}$. With photolysis, and for $\left[\mathrm{O}_{3}\right] \gg\left[\mathrm{NO}_{2}\right]$, the $\mathrm{I}_{\mathrm{x}} \mathrm{O}_{\mathrm{y}}$ forms become predominant. On the contrary, for $\left[\mathrm{O}_{3}\right] \ll\left[\mathrm{NO}_{2}\right]$, the iodine is mainly under $\mathrm{HI}, \mathrm{HOI}$ and $\mathrm{I}_{2}$ forms.

With a low iodine injection rate, the iodine is under $\mathrm{IONO}_{2}$ form, which turns to $\mathrm{I}_{\mathrm{x}} \mathrm{O}_{\mathrm{y}}$ with higher injection, highlighting a reaction cycle between iodine and the $\mathrm{NO}_{\mathrm{x}}$.

Assuming that the iodine oxides and nitroxides could nucleate to form aerosols (with different deposition rates), the iodine reactivity in the atmosphere could influence the iodine predicted deposits.

\subsection{Global mechanism base case}

The inorganic mechanism was completed with some organic reactions and coupled to RACM (Regional Atmospheric Chemical Mechanism, [1]), to be more realistic of the overall iodine reactivity.

The parameters of the Global Base Case are identical to the inorganic one (Table 1), to which were added volatile organic compounds (VOC) emission rates (Kuhn et al. [11]) and VOC initial concentrations. The pollutant reactivity 
Table 2: Iodine distribution (\%) at the last day of simulation (10 d.), at 12 am (white cells) and $12 \mathrm{pm}$ (gray cells).

\begin{tabular}{|c|c|c|c|c|c|c|c|}
\hline \multirow{2}{*}{ Species } & Base & \multicolumn{2}{|c|}{$\mathrm{R}=\left[\mathrm{O}_{3}\right] /\left[\mathrm{NO}_{2}\right]$} & \multicolumn{2}{c|}{ Photolysis } & \multicolumn{2}{c|}{ Injection } \\
\cline { 3 - 8 } & Case & $\mathrm{R}=1 / 500$ & $\mathrm{R}=500$ & January & None & $/ 100$ & $\times 100$ \\
\hline \multirow{2}{*}{$\mathrm{I}_{2}$} & 6.66 & 13.7 & 0.01 & 17.2 & 5.75 & 0.64 & 20.0 \\
& 9.45 & 48.7 & 0.41 & 10.5 & 5.84 & 0.30 & 15.9 \\
\hline \multirow{2}{*}{$\mathrm{HI}$} & 30.8 & 82.2 & 0.65 & 33.5 & 0.01 & 14.6 & 7.34 \\
& 2.66 & 12.0 & 0.07 & 0.86 & 0.01 & 0.95 & 0.95 \\
\hline \multirow{2}{*}{$\mathrm{HOI}$} & 0.42 & 0.53 & 0.12 & 2.24 & 4.48 & 0.11 & 0.80 \\
& 7.69 & 36.8 & 1.15 & 8.64 & 4.55 & 0.29 & 12.2 \\
\hline \multirow{2}{*}{$\mathrm{IONO}_{2}$} & 3.41 & 0.03 & 0.14 & 3.48 & 88.4 & 83.8 & 0.01 \\
& 22.3 & 2.25 & 1.23 & 37.5 & 88.1 & 98.4 & 0.03 \\
\hline \multirow{2}{*}{$\mathrm{I}_{2} \mathrm{O}_{5}$} & 56.2 & 0.01 & 96.6 & 40.6 & 0.55 & 0.05 & 43.5 \\
& 56.7 & 0.01 & 94.7 & 41.2 & 0.61 & 0.05 & 42.7 \\
\hline \multirow{2}{*}{$\mathrm{I}_{4} \mathrm{O}_{10}$} & 0.46 & $<10^{-2}$ & 1.37 & 0.24 & $<10^{-2}$ & $<10^{-2}$ & 27.9 \\
& 0.50 & $<10^{-2}$ & 1.39 & 0.26 & $<10^{-2}$ & $<10^{-2}$ & 28.2 \\
\hline
\end{tabular}

being included in RACM, the non-iodine species concentrations are not fixed but calculated. RACM regroup the species in 72 categories, so the non-iodine species have been converted to the RACM chemical categories. The initial VOC concentrations have been obtained with a simulation in the same conditions without iodine, including the VOC emissions rates from Kuhn et al. [11], by averaging the last day concentrations, the resulting values are detailed in Table 3. For this case, the iodine speciation is mainly under iodocarbon forms, such as $\mathrm{cC}_{5} \mathrm{H}_{9} \mathrm{I}$ (iodocyclopentane) or benzMI (iodomethylbenzene), that highlights the predominance of the organic part of the mechanism.

Table 3: Initial VOC concentrations for the global base case.

\begin{tabular}{|ll|ll|ll|ll|}
\hline ALD & $1.5 \mathrm{ppb}$ & HC5 & $1.20 \mathrm{ppb}$ & OLI & $0.50 \mathrm{ppt}$ & $\mathrm{SO} 2$ & $3.50 \mathrm{ppb}$ \\
CSL & $0.01 \mathrm{ppb}$ & HC8 & $1.00 \mathrm{ppb}$ & OLT & $15.0 \mathrm{ppt}$ & CO & $80.0 \mathrm{ppb}$ \\
ETE & $0.12 \mathrm{ppb}$ & HCHO & $4.00 \mathrm{ppb}$ & TOL & $0.25 \mathrm{ppb}$ & & \\
HC3 & $8.00 \mathrm{ppb}$ & KET & $10.0 \mathrm{ppb}$ & XYL & $0.50 \mathrm{ppb}$ & & \\
\hline
\end{tabular}


The iodocarbons are formed by several reactions of $\mathrm{I}$ and $\mathrm{I}_{2}$ with the VOC (HC3, HC5, ALD, TOL, ... ). However it remains an important lack of knowledge concerning the mechanism, with 25 unknown products, 11 non-destroyed species and only 13 photolysis reactions. Possible consequence would be to enhance the persistence of iodocarbons in the atmosphere.

\subsection{Global parameters sensibility studies}

In order to study the impact of the VOC on the iodine speciation, several cases have been examined with VOC initial concentrations only (IC only) and with VOC emission rates only (Em only). The iodine inlet as $\mathrm{I}_{2}$ has also been changed to $\mathrm{CH}_{3} \mathrm{I}\left(0.02\right.$ ppt.s $\left.{ }^{-1}\right)$ to get the iodine inlet form importance, $\mathrm{CH}_{3} \mathrm{I}$ being an other potential released gaseous species. The last day repartitions of iodine for this cases are presented in Table 4.

Table 4: Iodine distribution (\%) at the last day of simulation (10 d.), at 12 am (white cells) and $12 \mathrm{pm}$ (gray cells). HC3P*: RACM family, peroxides with 3 or less carbons.

\begin{tabular}{|c|c|c|c|c|}
\hline \multirow{2}{*}{$\begin{array}{c}\text { Species }- \\
\text { Reactions }\end{array}$} & Base & \multicolumn{2}{|c|}{ VOC } & Injection \\
\cline { 3 - 5 } & Case & Em only & IC only & $\mathrm{CH}_{3} \mathrm{I}$ \\
\hline $\mathrm{CH}_{2} \mathrm{CH}_{2} \mathrm{I}$ & 21.5 & 20.2 & 8.17 & 20.1 \\
and $\mathrm{CH}_{3} \mathrm{CHI}$ & 21.6 & 20.3 & 7.79 & 20.2 \\
\hline \multirow{2}{*}{$\mathrm{cC}_{5} \mathrm{H}_{9} \mathrm{I}$} & 11.5 & 12.3 & 0.54 & 16.5 \\
& 11.3 & 12.1 & 0.52 & 15.8 \\
\hline \multirow{2}{*}{ benzMI } & 9.17 & 10.1 & 0.68 & 10.1 \\
& 8.88 & 9.79 & 0.65 & 9.84 \\
\hline IO $+\mathrm{HC}^{*} \mathrm{P}^{*}$ & 6.48 & 5.75 & 3.01 & 6.78 \\
products & 6.47 & 5.81 & 2.86 & 6.72 \\
\hline \multirow{2}{*}{$\mathrm{CH}_{3} \mathrm{CH}{ }_{2} \mathrm{I}$} & 6.82 & 6.81 & 0.24 & 6.08 \\
& 6.20 & 6.20 & 0.20 & 5.38 \\
\hline \multirow{2}{*}{$\mathrm{CH}_{3} \mathrm{COI}$} & 4.78 & 3.97 & 10.8 & 5.30 \\
& 4.77 & 3.98 & 10.3 & 5.08 \\
\hline \multirow{2}{*}{$\mathrm{CH}_{3} \mathrm{I}$} & 0.26 & 0.30 & $<10^{-2}$ & 2.55 \\
& $<10^{-2}$ & $<10^{-2}$ & $<10^{-2}$ & 0.11 \\
\hline \multirow{2}{*}{ Inorganic Sum } & 2.44 & 1.65 & 68.4 & 3.61 \\
& 3.98 & 3.25 & 70.0 & 8.66 \\
\hline \multirow{2}{*}{} & & &
\end{tabular}


With VOC initial concentrations only, iodine species react to form iodocarbons until consuming all the VOC inventory. The pollutant reactivity $\left(\mathrm{O}_{3}, \mathrm{NO}_{\mathrm{x}}\right.$, VOC) lead to the formation of inorganic species like $\mathrm{I}_{2} \mathrm{O}_{5}$ and $\mathrm{IONO}_{2}$, which accumulates after the VOC consumption. With only VOC emission rates, the final iodine speciation is similar to the global base case. In the case with $\mathrm{CH}_{3} \mathrm{I}$ injection, the final speciation of iodine is also under iodocarbon forms. It is worth noticing the lower reactivity of $\mathrm{CH}_{3} \mathrm{I}$ with VOC compare to $\mathrm{I}_{2}$, due to a lower photolysis oxidation reaction.

The relevant impact is an increase of the inorganic sum fractions $\left(\mathrm{I}_{2} \mathrm{O}_{5}, \mathrm{IONO}_{2}\right)$ and $\mathrm{cC}_{5} \mathrm{H}_{9} \mathrm{I}$ (iodocyclopentane), and a decreasing of the $\mathrm{CH}_{2} \mathrm{CH}_{2} \mathrm{I}$ and $\mathrm{CH}_{3} \mathrm{CHI}$ fraction.

\subsection{Conclusions on the OD simulations}

Through the 0D simulations, iodine reactivity in atmospheric conditions is high and appears to be influenced by several parameters, such as the pollutant levels $\left(\mathrm{O}_{3}, \mathrm{NO}_{\mathrm{x}}\right.$, VOC), the photolysis rates (location, season, day/night cycle) and the iodine level. Concerning the inorganic behaviour, iodine is able to form iodine oxides $\left(\mathrm{I}_{\mathrm{x}} \mathrm{O}_{\mathrm{y}}\right)$, iodine nitroxide $\left(\mathrm{IONO}_{\mathrm{x}}\right)$ or molecular species $\left(\mathrm{I}_{2}, \mathrm{HI}, \mathrm{HOI}\right)$, depending on the conditions. When VOC are added to the box-model, iodocarbon forms become the dominant iodine species, which can be interpreted as a high reactivity of iodine with VOC. The dose-effect factor being different for organic than for inorganic compounds, the iodocarbon formation could be a relevant point.

However the lack of reactional paths for iodocarbons could also lead to their accumulation, which can bias the simulation results. Future theoretical works and experiments in atmospheric chamber has been planned to improve this iodine mechanism.

\section{3D simulations}

In order to study the iodine reactivity in mode relevant conditions, the 3Dchemical-transport code Polair3D-Chemistry [2] has been used, supported by the Polyphemus platform [3]. The selected 3D simulation domain is presented in Figure 3. The simulation are based on the same parameters than for the boxmodel studies, with the global iodine mechanism, a continuous inlet of $\mathrm{CH}_{3} \mathrm{I}$ at Gravelines location in France, during the ten days duration of the simulation. The pollutant concentrations come from MOZART (www2.acd.ucar.edu), the emission rates from EMEP (www.emep.int), and the meteorological fields are calculated with WRF (wrf-model.org/index.php).

The Figure 4 illustrate the dispersion calculated by the code. The analysis of the time concentrations shows that the iodocarbon forms are predominant, the inorganic fraction being insignificant $(\simeq 1.5 \%$ the night $)$. The calculated differences between day and night highlight the importance of the photolysis reactions, especially for the highest vertical levels where the photolysis rates are more consequent. The 3D simulations give the same trend than OD ones. However, 
the observed iodocarbons are not exactly the same, the differences being due to the more realistic VOC emissions used. It then appears in particular a relevant concentration of $\mathrm{iC}_{3} \mathrm{H}_{5} \mathrm{nI}\left(\mathrm{CH}_{2} \mathrm{CHCH}_{2} \mathrm{I}\right)$, coming from the reaction of $\mathrm{I}_{\text {or }} \mathrm{I}_{2}$ with toluene.

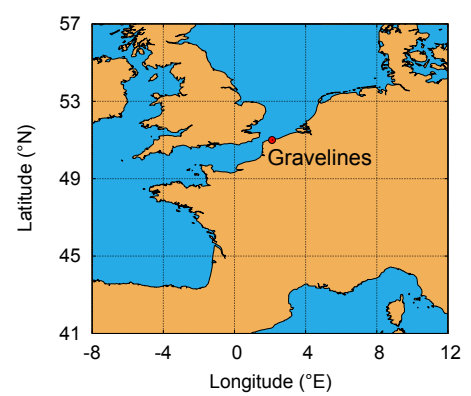

Figure 3: 3D simulation domain. Gravelines nuclear powerplant: iodine injection point.

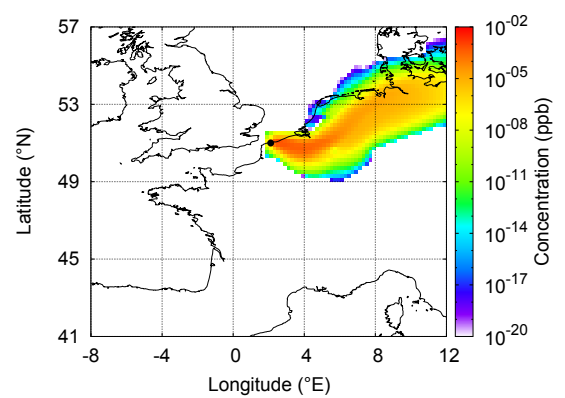

Figure 4: Concentration of $\mathrm{CH}_{3} \mathrm{I}$, after 12 hours of release, altitude: $0-50 \mathrm{~m}$.

\section{Conclusions}

Supported by the OD and 3D simulations, the iodine reactivity in the atmosphere seems to lead to various iodine speciation depending on the atmospheric boundary conditions. Without organic species, the final formation of iodine oxides $\mathrm{I}_{\mathrm{x}} \mathrm{O}_{\mathrm{y}}$ and $\mathrm{IONO}_{\mathrm{x}}$ has been obtained, with a repartition depending on the conditions such as the pollutant levels $\left(\mathrm{O}_{3}, \mathrm{NO}_{\mathrm{x}}\right)$, the photolysis rates (location, season, day/night cycle) and the iodine injection rate. The iodine oxides and nitroxides can nucleate to form aerosols with different transport properties. By taking into account the iodine reactivity, the simulated radioactive iodine transport should be improved.

However, when the organic species are added into the model, the iodine speciation become very different, with the predominance of the iodocarbon forms. With the current knowledge, the results show an accumulation of the organic iodine, for which there remains a lot of uncertainties, such as 25 unknown reaction products, 11 non-destroyed species, and only 13 photolysis reactions. For the inorganic part, the stability of iodine oxides in the atmosphere has to be deep because some possible reactions, for instance reduction of $\mathrm{I}_{\mathrm{x}} \mathrm{O}_{\mathrm{y}}$ by $\mathrm{CO}$ into $\mathrm{I}_{2}$, should be included but kinetic parameters are still unknown. The chemical mechanism should be further improved by a combination of experimental data and theoretical chemistry works. Finally, the development of an aerosol modeling module should be considered, to treat radioactive iodine aerosol behaviour in the dispersion softwares. 


\section{References}

[1] Stockwell, W.R., Kirchner, F., Kuhn, M. \& Seefeld, S., A new mechanism for regional atmospheric chemistry modeling. J Geophysic Research, 1997.

[2] Boutahar, J., Lacour, S. \& Mallet, V., Development and validation of a fully modular platform for numerical modelling of air pollution: POLAIR. Int $J$ Env Pollut, 22, pp. 17-28, 2004.

[3] Quelo, D., Krysta, M., Bocquet, M., Isnard, O., Minier, Y. \& Sportisse, B., Validation of the Polyphemus platform on the ETEX, Chernobyl and Algeciras cases. Atm Environment, 41, pp. 5300-5315, 2007.

[4] Vogt, R., Sander, R., Von-Glasow, R. \& Crutzen, P., Iodine chemistry and its role in halogen activation and ozone loss in the marin boundary layer: a model study. J Atmospheric Chemistry, 32, pp. 375-395, 1999.

[5] McFiggans, G., Plane, J., Beverley, J. \& Carpenter, L., A modeling study of iodine chemistry in the marine boundary layer. J Geophysic Research, 105, pp. 14,371-14,385, 2000.

[6] Calvert, J. \& Lindberg, S., Potential influence of iodine-containing compounds on the chemistry of the troposphere in the polar spring. I ozone depletion. Atm Environment, 38, pp. 5087-5104, 2004.

[7] Mahajan, A., Oetjen, H., Saiz-Lopez, A., Lee, J., McFiggans, G. \& Plane, J., Reactive iodine in a semi-polluted environment. Geophys Res Lett, 36, p. L16803, 2009.

[8] Saiz-Lopez, A., Plane, J., Baker, A., Carpenter, L., Von-Glasow, R., GomezMartin, J., McFiggans, G. \& Saunders, R., Atmospheric chemistry of iodine. Chemical Reviews, 2011.

[9] Ordonez, C., Lamarque, J., Tilmes, S., Kinnison, D., Atlas, E., Blake, D., Sousa-Santos, G., Brasseur, G. \& Saiz-Lopez, A., Bromine and iodine chemistry in a global chemistry-climate model: description and evaluation of very short-lived oceanic sources. Atmos Chem Phys, 12, pp. 1423-1447, 2012.

[10] Sommariva, R., Bloss, W. \& Von-Glasow, R., Uncertainties in the gas-phase atmospheric iodine chemistry. Atm Environment, 57, pp. 219-232, 2012.

[11] Kuhn, M., Builtjes, P.J.H., Poppe, D., Simpson, D., Stockwell, W.R., Andersson-Skold, Y., Baart, A., Das, M., Fiedler, F., Hov, O., Kirchner, F., Makar, P.A., Milford, J.B., Roemer, M.G.M., Ruhnke, R., Strand, A., Vogel, B. \& Vogel, H., Intercomparison of the gas-phase chemistry in several chemistry and transport models. Atm Environment, 32, pp. 693-709, 1998. 